\title{
The use of heated models to describe the thermal environment in shelters for farm animals
}

\author{
MARKUS PYYKKÖNEN \\ PyykKönen, M. 1992. The use of heated models to describe the thermal environment \\ in shelters for farm animals. Agric. Sci. Finl. 1: 539-545. (Dept. Agric. Eng. and \\ Household Tech., Viikki F, SF-00014 University of Helsinki, Finland.)

\begin{abstract}
The dry bulb air temperature is still the most commonly used parameter to characterize the thermal environment, even though it disregards the effect of air velocity and the thermal properties of the flooring material on the heat loss from the animal.

Measurements in the laboratory confirmed that an uninsulated heated model with an overall thermal resistance of $0.11 \mathrm{~m}^{2} \mathrm{KW}^{-1}$ is sensitive enough to differentiate between changes in conduction, convection and radiation conditions.

Measurements on farms showed that the heat loss simulated by mechanical models gives a more diversified description of the thermal environment than the dry bulb air temperature. Although the uninsulated mechanical model is not a standardized device, it is a useful method for measuring the thermal environment especially under sheltered winter conditions.
\end{abstract}

Key words: heat dissipating model, heat loss, sensible heat loss, dry bulb air temperature

\section{Introduction}

Mathematical animal heat loss models are used in converting the heat loss data obtained in feeding experiments into design values for ventilation engineers. In these conversions, gross simplifications are introduced, i.e. the heat loss is only a function of air temperature, live weight and production level (STRÖM and ZhANG 1989). This approach is a major reason why the dry bulb air temperature measured at a representative location is still the parameter most commonly used to characterize the thermal environment (HAHN et al. 1983) in practice. Another reason may be the abundance of simple and reliable methods for measuring the air temperature. Anyway, the dry bulb air temperature dis- regards the effect of air velocity and the flooring material on the heat loss from the animals. It also disregards the radiative heat loss.

The quantification of the thermal environment would be more accurate if the dry bulb air temperature were replaced by an effective temperature combining the cooling effect of convection, conduction and radiation with the cooling capacity of evaporation.

The aim of this project was to develop a method to simulate the sensible heat loss from the animals in order to obtain a good characterization of the thermal environment at the level of the individual animal on farms and to study whether the characterization given by the heat dissipating model is different from that given by the dry bulb air temper- 
ature. The method was to be sensitive enough to measure the small changes in the environment in order to evaluate the function of the ventilation system from the thermal point of view. The model was to be suitable for continuous measurement in pens even in the presence of animals.

\section{Review of the literature}

The cooling effect of the environment has been measured with a katathermometer (MOTHES 1971, TRIPPE 1984, KUNZ 1985) which mesures the time needed for a heated bulb to cool from $35^{\circ} \mathrm{C}$ to $30^{\circ} \mathrm{C}$. The cooling effect, measured by the katathermometer, does not measure the total heat loss from the animal. It gives an estimate of the maximum heat loss to the surrounding air (TRIPPE 1984), but it disregards the heat loss by conduction to the floor, which is important for juvenile animals spending most of their time lying.

The heat loss from animals has been simulated by heat dissipating models. These models generally include the following assumptions (HAHN and BÖE 1985):

1. ignoring the evaporative component of energy exchange,

2. the use of uniform thermal insulation over the total surface of the model,

3. a level of thermal insulation corresponding to the vasoconstricted state of the animal,

4. no postural adjustments.

In the simplest heat dissipating models the heat flow from the warm body was calculated from the cooling time for a certain temperature interval (NYGAARD 1966). This introduced the problem of changing temperature difference during the measurement. The problem was usually solved by measuring the cooling time for a narrow temperature inter$\mathrm{val}$, and by calculating the temperature difference from the average temperature difference during the measurement.

Insulated full-scale cow models have been used in estimating the feed energy requirement of beef cattle and suckler cows under unsheltered winter conditions (WEBSTER 1971, BURNETT and BRUCE 1987). The models were based on a constant internal temperature and on an overall thermal insulation, corresponding to that of a real animal. They ignored the evaporative component of energy exchange. A cylindrical 0.4 -scale model gave similar thermal responses in a changing climate as the full-scale model (JONES 1982).

Two heated models, one insulated, of the size and overall thermal resistance of a $40 \mathrm{~kg}$ lamb, and another uninsulated black copper sphere were used by HAHN and BÖE (1985) in estimating the energy demand of lambs in different environments. The models were placed at a height of $0.5 \mathrm{~m}$ above the floor. The results of the two models were highly correlated $(r=0.96)$. The good correlation between the heating requirements of insulated and uninsulated models indicates that uninsulated models could provide an acceptable measure of the thermal environment (HAHN and BÖE 1985). The sensible heat flow from heat dissipating models is essentially the same as that from real animals, as summarized by the equation presented by ESMAY and DIXON (1986):

$\mathrm{Q}_{\mathrm{s}}=\mathrm{A} * \mathrm{c} *\left(\mathrm{~T}_{\mathrm{a}}-\mathrm{T}_{\mathrm{e}}\right)$

where: $\mathrm{Q}_{\mathrm{s}}=$ sensible heat loss, $\mathrm{W} ; \mathrm{A}=$ surface area of animal; $\mathrm{T}_{\mathrm{a}}=$ surface temperature of animal, $\mathrm{K}$; $\mathrm{T}_{\mathrm{e}}=$ average temperature of surroundings, $\mathrm{K} ; \mathrm{c}=$ overall sensible heat transfer coefficient.

\section{Construction of the heated model}

To test whether uninsulated heated models provide an acceptable measure of the thermal environment, a heated model with an overall thermal resistance of $0.11 \mathrm{~m}^{2} \mathrm{KW}^{-1}$ was constructed. The surface area of the model was chosen so that the contact area of the model to the floor, $23.3 \%$ of the total surface, was about the same as that of a lying animal, which is about 20\% (GOMMERS et al. 1970). 


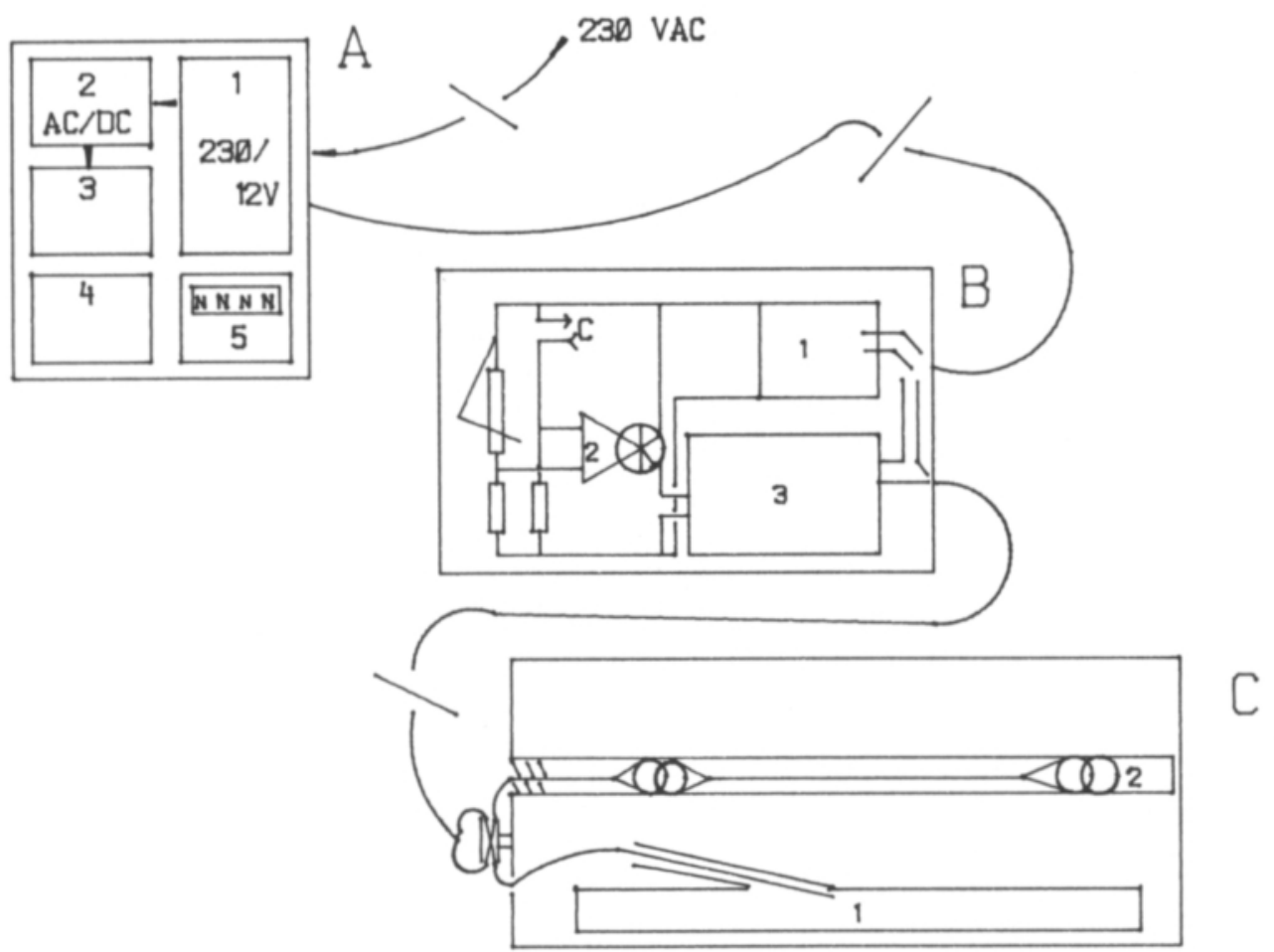

Fig. 1. Working principle of the heated model.

A Voltage supply and registering unit

A1 Transformer

A2 Rectifier and voltage stabilizer

A 3 Voltage regulator and stabilizer

A4 Relay switch for the timer A5

A5 Timer

B Regulating unit

B1 Regulation of the control voltage

B2 Comparator

B3 Relay for the heating voltage, B2 controlling the relay.

C Measuring device

C1 Heating element (approx. 5 ohm)

C2 Sensor tube with two thermistors

With a given resistance and a constant voltage, the energy requirement of an electrically heated model can be calculated by measuring the time for the power to be switched on, and by multiplying it by the electrical power. The heat loss from the model $\left(\mathrm{Wm}^{-2}\right)$ is then computed by division by the total measuring time and the surface area of the model.

The heated model was made of a standard alumi- nium box used in electronics $(125 * 80 * 57.5 \mathrm{~mm})$ which was filled with ethylene glycol $(50 \%)$. The amount of fluid was $0.3 \mathrm{~kg}$. The mean temperature of the fluid during a heating cycle was $32.5^{\circ} \mathrm{C}$, ranging from $31.5^{\circ} \mathrm{C}$ to $33.5^{\circ} \mathrm{C}$. The model was heated with a heating element, placed about $2 \mathrm{~mm}$ from the bottom surface of the vessel. The heating was controlled through a thermistor, which started and stopped a timer when switching the heating on 
Table 1. Coefficients of the regression lines between the temperature difference and the heat loss for the different flooring materials with the heated model.

\begin{tabular}{lccc}
\hline $\begin{array}{l}\text { Flooring } \\
\text { material }\end{array}$ & $\begin{array}{c}\text { Coefficient of } \\
\text { determination }\end{array}$ & $\begin{array}{c}\text { Intercept } \\
\mathrm{a}\end{array}$ & $\begin{array}{c}\text { Coefficient } \\
\mathrm{b}\end{array}$ \\
\hline Concrete & 0.99 & -31.2 & $14.3^{* * *}$ \\
Plastic & 0.99 & -21.7 & $11.2^{* * * *}$ \\
Steel & 0.98 & -19.1 & $15.4^{* * *}$ \\
Straw & 0.99 & -17.2 & $8.6^{* * *}$ \\
Wood & 0.99 & -26.1 & $11.2^{* * *}$ \\
\hline
\end{tabular}

$* * * \mathrm{p}<0.1 \%$

and off. The working principle of the model is shown in Figure 1.

The temperature difference, defined as the difference between the ambient temperature at the floor level and the mean temperature measured in the sensor tube during a heating cycle of the model, explained $98-99 \%$ of the variation of the heat loss from the model in the laboratory which is in agreement with the general laws of sensible heat flow (Table 1). These results indicate that the accuracy of the method is acceptable. When the temperature difference ranged from $7^{\circ} \mathrm{C}$ to $30^{\circ} \mathrm{C}$, the linear regression line was:

$\mathrm{Q}=\mathrm{a}+\mathrm{bdT}$

where: $\mathrm{dT}=$ temperature difference, ${ }^{\circ} \mathrm{C} ; \mathrm{Q}=$ heat loss from the model, $\mathrm{Wm}^{-2}$.

The values of the intercepts and the coefficients of the regression lines for the different flooring materials are presented in Table 1. The fact that the regression coefficients calculated for the floor materials are different indicates that the model differentiates between conduction conditions which may occur in practice.

The effect of air velocity on the heat loss from the model was measured in a wind tunnel. To be able to maintain a constant temperature of the moving air, an air temperature of $15^{\circ} \mathrm{C}$ was used which corresponds to the temperature generally used in calf shelters. The regression between the air velocity ranging from $0 \mathrm{~ms}^{-2}$ to $1 \mathrm{~ms}^{-2}$ and the heat loss from the model was:

$\mathrm{Q}=282.7+6.9 *\left(\mathrm{v}^{-1}\right)-78.5 * \ln \left(\mathrm{v}^{-1}\right) ;\left(\mathrm{r}^{2}=0.99\right)$

where: $\mathrm{v}=$ air velocity, $\mathrm{ms}^{-1} ; \mathrm{Q}=$ heat loss from the model, $\mathrm{Wm}^{-2}$.

The temperature of the upper surface of the model decreased with increasing air velocity, which explained the non-linearity of the regression between the air velocity and the heat loss in agreement with the general theory of convection.

These results confirm the conclusion that an uninsulated heated model with an overall thermal resistance of less than $0.11 \mathrm{~m}^{2} \mathrm{KW}^{-1}$ can differentiate between conduction and convection conditions which may occur in practice.

\section{Measurements on farms}

The first farm tests on the model were made in cow shelters, simultaneously in a calf pen with a wooden slatted floor on Suitia experimental farm and in an uninsulated shelter with deep litter at Muurla, an experiment run by the College of Veterinary Medicine (between 2 Feb and 22 Mar, 1990).

Additional tests were made in three piggeries, in farrowing house A between $27 \mathrm{Mar}$ and $6 \mathrm{Apr}$, 1990 and in farrowing houses B and C between 14 Feb and $15 \mathrm{Apr}, 1991$. In the piggeries the model was placed on concrete floor in the farrowing pen in the lying area of the piglets, with $20-30 \mathrm{~mm}$ of straw under the model. In farrowing house $\mathrm{C}$ there were hot water heating tubes under the littered lying area. In the weaner house of piggery $\mathrm{C}$ the model was placed on a slatted floor made of galvanized welded mesh. There were animals in the pen during the measurements in the weaner house and at Muurla.

On the farms, the dry bulb air temperature, i.e. the ambient temperature, was measured with $\mathrm{Hg}$ thermometers at an accuracy of $0.1^{\circ} \mathrm{C}$. The values of the thermometers were read daily at 8.30 a.m. and $4.30 \mathrm{p} . \mathrm{m}$. The function of the thermostat of the 
Table 2. Thermal environment as weekly means in a pen at Suitia and in an uninsulated shelter at Muurla.

\begin{tabular}{lcccc}
\hline Period & \multicolumn{2}{c}{ Heat loss, $\mathrm{Wm}^{-2}$} & \multicolumn{3}{c}{ Ambient temperature, ${ }^{\circ} \mathrm{C}$} \\
& Suitia & Muurla & Suitia & Muurla \\
\hline 2-9 Feb & 211.8 & 199.1 & 13.5 & 3.3 \\
9-16 Feb & 211.0 & 230.8 & 13.5 & 1.5 \\
16-23 Feb & 212.7 & 205.4 & 13.5 & 1.1 \\
15-22 Mar & 188.8 & 175.6 & 13.5 & 4.3 \\
Mean & 206.1 & 202.7 & 13.5 & 2.6 \\
S.D. & 11.5 & 22.7 & 0.0 & 1.3 \\
t-value & $0.27^{\text {ns }}$ & & & \\
\hline
\end{tabular}

${ }^{n s}$ not significant

ventilation system was tested with a thermohygrograf at an accuracy of $1{ }^{\circ} \mathrm{C}$.

\section{Results from the cow shelters}

The heat loss was measured in one week periods over five weeks. The lowest outside air temperature was $-11.0^{\circ} \mathrm{C}$, and the weekly means varied from $-1.1^{\circ} \mathrm{C}$ to $+2.8^{\circ} \mathrm{C}$.

The average ambient temperature was $13.5^{\circ} \mathrm{C}$ at Suitia, ranging from $12^{\circ} \mathrm{C}$ to $15^{\circ} \mathrm{C}$. The weekly means of the ambient temperature varied from $+1.1^{\circ} \mathrm{C}$ to $+4.3^{\circ} \mathrm{C}$ in the uninsulated shelter at Muurla. The heat loss was $206.1 \pm 11.5 \mathrm{Wm}^{-2}$ in the pen and $202.7 \pm 22.7 \mathrm{Wm}^{-2}$ in the shelter (Table 2).

The difference in the thermal environment between the pen at Suitia and the uninsulated shelter with deep litter at Muurla is obvious, if the environment is described by the ambient temperature. If the thermal environment is described by the heat loss from the heated model, there was no difference between the environments. The heat loss in the uninsulated shelter was highly influenced by the heat produced by fermentation in the deep litter.

\section{Results from the piggeries}

There were significant differences in the heat loss measured by the model when placed in different
Table 3. Heat loss from the model in farrowing houses.

\begin{tabular}{|c|c|c|c|}
\hline \multirow{2}{*}{ Parameter } & \multicolumn{3}{|c|}{ Farrowing house } \\
\hline & A & $\mathrm{B}$ & $\mathrm{C}$ \\
\hline Mean ambient temperature, ${ }^{\circ} \mathrm{C}$ & 19 & 19 & 19 \\
\hline Measuring period, days & 11 & 17 & 5 \\
\hline Observations & 22 & 34 & 10 \\
\hline $\begin{array}{l}\text { Mean heat loss from the } \\
\text { model, } \mathrm{Wm}^{-2}\end{array}$ & $153^{\mathrm{a}}$ & $104^{\mathrm{c}}$ & $110^{b}$ \\
\hline S.D., $\mathrm{Wm}^{-2}$ & 9.6 & 8.1 & 3.4 \\
\hline
\end{tabular}

Table 4. Heat loss from the model in farrowing house $\mathrm{C}$ and in weaner house of the same farm before and after reducing the ventilation rate.

\begin{tabular}{lccc}
\hline Parameter & $\begin{array}{c}\text { Farrowin } \\
\text { g house }\end{array}$ & \multicolumn{2}{c}{ Weaner house } \\
& & before & after \\
\hline Observations & 10 & 8 & 9 \\
Mean ambient temperature, ${ }^{\circ} \mathrm{C}$ & 19 & 24 & 24 \\
${\text { Mean heat loss, } \mathrm{Wm}^{-2}}^{\text {S.D., Wm }}{ }^{-2}$ & $110^{\mathrm{a}}$ & $133^{\mathrm{c}}$ & $108^{\mathrm{b}}$ \\
\hline
\end{tabular}

a,b significant differences are shown by different letters, $\mathrm{p}>0.01$

farrowing houses even though the measured average ambient temperatures were the same, $19^{\circ} \mathrm{C}$ (Table 3).

The difference in the heat loss between farrowing house $\mathrm{A}$ and farrowing house $\mathrm{B}$, about 50 $\mathrm{Wm}^{-2}$, corresponds to an increase of air velocity of $0.2 \mathrm{~ms}^{-2}$ at an air temperature of $19^{\circ} \mathrm{C}$.

The thermal environment of farrowing house $\mathrm{C}$ was compared to that of the weaner house of the same farm. Despite the higher ambient temperature the heat loss from the model was higher in the weaner house (Table 4). After reducing the air velocity at the floor level by decreasing the ventilation rate in the weaner house, the difference in the heat loss disappeared. 


\section{Conclusions}

The measurements on the farms showed that the dry bulb air temperature does not always give an accurate picture of the thermal environment. In conditions where animals should be sheltered free from draft, the heat loss simulated by mechanical models gives a more diversified description than the air temperature. These results completely agree with the conclusion of HAHN and BÖE (1985) that uninsulated models can provide an acceptable method of measuring the thermal environment.

The model is not able to regulate the heat loss, which in combination with the rather low heat resistance of $0.11 \mathrm{~m}^{2} \mathrm{KW}^{-1}$ means that the model is more sensitive to changes in the environment than a live animal. The sensitivity of the model is not a disadvantage however, as the function of the ventilation system is measured. Even small changes in the environment can be detected with the model. Altough the model does not measure the heat loss from the animal, it gives an estimate of the maximum sensible heat loss. In this respect it resembles the katathermometer used by TRIPPE (1984).

The measurements on farms showed that the heated model was durable enough to be used on farms, even on the floor in pens where there are animals. Yet, the model cannot be used in unsheltered winter conditions, where the heat loss from the model exceeds $450 \mathrm{Wm}^{-2}$. A heat loss of $465 \mathrm{Wm}^{-2}$ means that the heating element is switched on all the time.

Although the uninsulated model is not a standardized device for measuring the thermal environment, it is a useful method especially under sheltered winter conditions as indicated by the measurements on the farms. The model can be used to adjust the ventilation and to estimate the effect of a change in the thermal environment, except a change in the relative humidity, on the heat loss from the animals. In studying the correlation between the thermal environment and the animal health the model provides a better description of the thermal environment than that given by the dry bulb air temperature.

As the thermal properties of the model are known, it is possible to calculate the corresponding effective temperature where the heat loss is only a function of the temperature. The effective temperature can then be used in the mathematical animal heat loss models to estimate the heat loss from animals in the situation measured.

\section{References}

Burnett, G. A. \& Bruce, J. M. 1978. Thermal simulation of suckler cow. Farm Bldg. Progress 54: 11-13.

Esmay, L. M. \& Dixon, J. E. 1986. Environmental control for agricultural buildings. 287 p. Westport, Connecticut.

HAнn, G. L. \& BöE, K. 1985. Evaluating thermal demand in cold sheep housing. ASAE-paper no. MCR 85-150. 11 p.

—, NygaArd, A. \& Simensen, E. 1983. Towards establishing rational criteria for selection and design of livestock environments. ASAE-paper 83-4517.

Gommers, F. I., Cristison, G. I. \& Curtis, S. E. 1970. Estimating animal floor contact areas. J. Anim. Sci. 40: 552-555.

JoNES, C. G. 1982. Modelling the integrated climatic energy demand on animals. Interim report to the Agricultural Research Council (U.K.). 12 p.

Kunz, P. 1985. Kälberhaltung in Hütten. FAT-Berichte 269 $12 \mathrm{p}$.

Mothes, E. 1971. Stallklima. 196 p. Berlin.

NILsson, C. 1988. Floors in animal houses. Institutionen för lantbrukets byggnadsteknik. Rapport 61 .

Ström, J. S. \& Zhang, G. 1989. Thermal control in animal buildings. In: Dodd, V. A. \& Grace, P. M. (eds.). Agricultural engineering 2. Rotterdam. p. 1265-1278.

TRIPPE, M. 1984. Prüfung des Kriteriums Abkühlungsgrösse auf seine Eignung zur weitergehenden Charakterisierung des Mikroklimas in Tierställen. Institut für Tierhygiene der Tierärtzlichen Hochschule Hannover. 106 p.

Webster, A. J. F. 1971. Prediction of heat losses from cattle exposed to cold outdoor environments. J. Appl. Physio. 30: 684-690.

\section{Manuscript received April 1992}

Markus Pyykkönen

Department of Agricultural Engineering and Household Technology

Viikki F

SF-00014 University of Helsinki, Finland 


\title{
SELOSTUS
}

\section{Termisen ympäristön mittaaminen eläinsuojissa}

\author{
MARKUS PYYKKÖNEN
}

Helsingin yliopisto

Ilman keskimääräistä lämpötilaa käytetään yleisesti kuvaamaan eläinsuojien termistä ympäristöä. Ilman lämpötila ei sisällä tietoa ilman liikenopeuden eikä lattiamateriaalin vaikutuksesta eläimen lämmönluovutukseen.

Eläinmallin luovuttamaa lämpömäärää voi periaatteessa käyttää eläimen termisen ympäristön kuvaamiseen, sillä mallin vapaa lämmönluovutus on samojen fysiikan lakien alainen kuin eläimen vapaa lämmönluovutus. Jotta termisen ympäristön jatkuva mittaaminen olisi mahdollista, rakennettiin lämmitettävä mekaaninen malli, jonka lämpövastus oli $0,11 \mathrm{~m}^{2}$ $\mathrm{KW}^{-1}$.

Lämmitettävänä mallina käytettiin etyleeniglykolilla (50 $\%)$ täytettyä alumiiniastiaa $(125 * 80 * 57,5 \mathrm{~mm})$. Nesteen määrä oli $0,3 \mathrm{~kg}$. Lämmitysvastuksen sisältävä kuparikotelo oli $2 \mathrm{~mm}$ alumiiniastian pohjan yläpuolella. Lämmitystä ohjaava termistori kytki käyttöjännitteen aikalaskuriin, joka oli aina kytkettynä päälle lämmitysvastuksen lämmittäessä.

Koska teho $\mathrm{P}=\mathrm{U}^{2} * \mathrm{R}^{-1}$, niin mallin luovuttama lämpömäärä on lämmitysajan ja tehon tulo, kun vastus ja jännite ovat vakioidut. Mallin luovuttama vapaa lämpö saadaan jakamalla lämpömäärä mittausajalla ja mallin pinta-alalla.

Lämmitettävää mallia kokeiltiin käytännön olosuhteissa Suitian koetilalla vasikkakarsinassa, jossa oli puinen rakolattia, ja eristämättömässä olkipohjaisessa makuusuojassa Muurlassa. Lämmönluovutus mitattiin viikon jaksoissa viiden viikon aikana.

Olosuhteissa oli selvä ero, kun niitä kuvattiin ympäristön lämpötilalla, sillä karsinassa lämpötila oli $13,5^{\circ} \mathrm{C}$ ja makuusuojassa $2,6^{\circ} \mathrm{C}$. Mallin lämmönluovutuksen perusteella ei olosuhteissa ollut eroa, sillä mallin lämmönluovutus karsinassa oli $206,1 \pm 11,5 \mathrm{Wm}^{-2}$ ja makuusuojassa $202,7 \pm 22,7 \mathrm{Wm}^{-2}$.

Mallin avulla mitattiin porsituskarsinan termistä ympäristöä kolmessa sikalassa. Vaikka ilman lämpötilan asetusarvo oli kaikissa sikaloissa $19^{\circ} \mathrm{C}$, niin mallin lämmönluovutus oli tilastollisesti merkitsevästi erilainen eri sikaloissa. Ero suurimman ja pienimmän lämmönluovutuksen välillä, noin $50 \mathrm{Wm}^{-2}$, vastaa $0,2 \mathrm{~ms}^{-1}$ eroa ilman nopeudessa.

Sikalassa $\mathrm{C}$ mallin lämmönluovutus varhaisvieroitusosastossa $\left(133 \mathrm{Wm}^{-2}\right)$ oli suurempi kuin porsituskarsinassa (110 $\mathrm{Wm}^{-2}$ ), vaikka ilman lämpötila oli $27^{\circ} \mathrm{C}$ varhaisvieroitusosastossa. Kun ilmanvaihdon säätöä muutettiin varhaisvieroitusosastossa, mallin lämmönluovutus oli yhtä suuri $\left(108 \mathrm{Wm}^{-2}\right)$ kuin porsituskarsinassa.

Mittaukset osoittivat, että ilman lämpötila ei aina anna tarkkaa kuvaa termisestä ympäristöstä. Lämpöä luovuttavat mallit antavat monipuolisemman kuvan termisestä ympäristöstä kuin ympäristön lämpötila ja mallien avulla voidaan mitata eläinten oleskelualueella tapahtuvat termisen ympäristön muutokset. 